\title{
ANTIOXIDANT ACTIVITIES AND PHENOLIC COMPOUNDS IN FRUITS OF VARIOUS GENOTYPES OF AMERICAN PERSIMMON (DIOSPYROS VIRGINIANA L.)
}

\author{
Olga Grygorieva ${ }^{1 凶}$, Alicja Zofia Kucharska², Narcyz Piórecki ${ }^{3,4}$, Svitlana Klymenko ${ }^{1}$, \\ Olena Vergun ${ }^{1}$, Ján Brindza ${ }^{5}$ \\ ${ }^{1}$ M. M. Gryshko National Botanical Gardens of Ukraine, National Academy of Sciences \\ Timiryazevska 1, 01014 Kyiv, Ukraine \\ ${ }^{2}$ Department of Fruit, Vegetable and Plant Nutraceutical Technology, Wrocław University of Environmental and Life Sciences \\ Norwida 25/27, 50-375 Wrocław, Poland \\ ${ }^{3}$ Arboretum and Institute of Physiography in Bolestraszyce \\ P.O. box 471, 37-700 Przemyśl, Poland \\ ${ }^{4}$ Department of Tourism and Recreation, University of Rzeszów \\ Towarnickiego 3, 35-959 Rzeszów, Poland \\ Institute of Biological Conservation and Biosafety, Slovak University of Agriculutre in Nitra \\ Trieda Andreja Hlinku 2, 94976 Nitra, Slovakia
}

\begin{abstract}
Background. American persimmons (Diospyros virginiana L.) are known as a widespread cultivar which were traditionally used by Native Americans as a food source, and since ancient times have been used in folk medicine. The objective of this study was to evaluate the antioxidant activity and phenolic content of Diospyros virginiana genotypes.

Material and methods. The content of the total antioxidant activity and phenolic compounds from the fruits of the American persimmon (Diospyros virginiana L.) of six genotypes were compared. Antioxidant activity (AOA) was measured using three different photometric methods - DPPH (2,2-diphenyl-1-picrylhydrazyl), ABTS (2,2-azino-bis-3-ethylbenzothiazoline-6-sulfonic acid) and FRAP (ferric-reducing antioxidant power). Total phenolic content (TPC) was evaluated using Folin-Ciocalteu reagent assay.

Results. The results for AOA ( $\mu \mathrm{Mol}$ Trolox/g) determined by the DPPH method varied from 51.68 (DV-05) to 100.87 (DV-03), those obtained by the ABTS method varied from 65.40 (DV-05) to 142.26 (DV-03), and those obtained by the FRAP method varied from 45.06 (DV-05) to 109.30 (DV-03). The results for TPC varied from $590.75 \pm 27.98 \mathrm{mg} / 100 \mathrm{~g}$ (DV-05) to $1325.12 \pm 77.30 \mathrm{mg} / 100 \mathrm{~g}$ (DV-03). The highest results for AOA and TPC were achieved for the fruits of genotypes DV-03 and DV-05. A positive linear correlation was found between antioxidant activity and total phenolic content in the examined plant material.

Conclusion. The results showed that all fruit extracts exhibited strong antioxidant activities, which generally correlated positively with the total phenolic content. This study demonstrates the potential of the fruits of Diospyros virginiana grown in Ukraine as a possible source of valuable polyphenol content, with high antioxidant activities and health-promoting properties. The high contents of phenolic compounds and significant linear correlation between the values of the concentration of phenolic compounds and antioxidant activity indicated that these compounds contributed to the strong antioxidant activity.
\end{abstract}

Keywords: American persimmon, fruit, antioxidant activity, phenolic compounds

\footnotetext{
®olgrygorieva@gmail.com
} 


\section{INTRODUCTION}

Only in recent years has the search for new sources of antioxidants and polyphenols in fruits of less popular orchard plants been widely reported: Vaccinium corymbosum L. (Ścibisz and Mitek, 2007), Cornus mas L., Chaenomeles japonica (Thunb.) Lindl. ex Spach (Nawirska-Olszańska et al., 2011), Prunus spinosa L. (Sikora et al., 2013), Actinidia arguta (Siebold \& Zucc.) Planch. ex Miq., Crataegus monogyna Jacq., Gaultheria procumbens L., Schisandra chinensis (Turcz.) Baill. (Pliszka et al., 2016), Morus nigra L. (Kucelova et al., 2016), Ziziphus jujuba Mill. (Ivanišová et al., 2017).

American persimmons (Diospyros virginiana L.) a widespread fruit used traditionally by Native Americans as a source of food, and since ancient times have also been used in folk medicine (Briand, 2005; Foster and Duke, 1999; Hamel and Chiltoskey, 1975; Mallavadhani et al., 1998; Ross et al., 2014).

The fruits of the persimmon are an excellent dietary product. They are consumed fresh and pastes, jams, syrups, and marinades can be made from them. The fruits have also been used to make wine, brandy, white wine vinegar and beer (Bartram, 1772; Briand, 2005). Additionally, the by-products from processing persimmon fruits or leaves can be used in animal nutrition as a source of bioactive compounds (Gálik et al., 2016; Herkel' et al., 2016) and thereby improve the performance of farm animals.

Leaves, fruits, calyx and seeds contain $\left(\mathrm{g} \cdot \mathrm{kg}^{-1}\right)$ protein $-123.6,33.2,218.4,128.1$, and cellulose -138.8 , 37.9, 158.4, 182.0. Lipids - $9.10 \mathrm{~g} \cdot \mathrm{kg}^{-1}$, fructose $9.56 \%$, glucose $-10.67 \%$ (Grygorieva et al., 2009), ascorbic acid - 30.11-49.7 mg\% (Grygorieva et al., 2012) have also been detected in the fruits, alongside 106 volatile compounds, of which 83 have been identified. These include alcohols, saturated and unsaturated aldehydes, ketones, fatty acids, esters and terpenoids (Grygorieva et al., 2017).

The leaves accumulate lupeol, betulin, betulinic acid (Shukla et al., 1989), catechins, leucoanthocyanins, anthocyanins, saponins and other compounds (Chetverikova et al., 1959). The leaves of Diospyros virginiana, by biochemical composition, have the highest content of ascorbic acid and mineral compounds compared to other species (Grygorieva et al.,
2012; Richter, 2001). Some investigations reported the presence of the betulinaldehyde and ursulic acid in the roots of these plants (Wang et al., 2011).

The fruits demonstrate a positive effect on the central nervous system; the complex of biologically active compounds stimulates the activity of endocrine glands, promotes better iron absorption, improved hematopoiesis, prevents the formation of carcinogens and cholesterol stones in the gallbladder, influences the intracellular hepatic circulation of bile acids, and stimulates bactericidal action on colon bacillus (Escherichia coli), and aurococcus (Staphylococcus aureus) (Mallavadhani et al., 1998). The fruits and leaves have antifungal (Wang et al., 2011), antimicrobial (Charley et al., 1999; Isfahani et al., 2014) and antitumor (Shukla et al., 1989) effects. The bark has antiseptic (Briand, 2005), hepatoprotective and antipyretic (Priya and Nethaji, 2014; 2015) effects. Teas made from American persimmon leaves are a caffeine-free healthy alternative to black or green tea (Kobayashi et al., 2017).

The objective of this study was to evaluate the antioxidant activity and phenolic content of six Diospyros virginiana genotypes. The obtained data shows that the investigated plants have potent antioxidant activity, that can be used for the further investigation and utilization of Diospyros virginiana.

\section{MATERIAL AND METHODS}

\section{Biological material}

The fruits (Fig. 1) of 6 genotypes of Diospyros virginiana (DV-1-DV-6) collected in the M. M. Gryshko

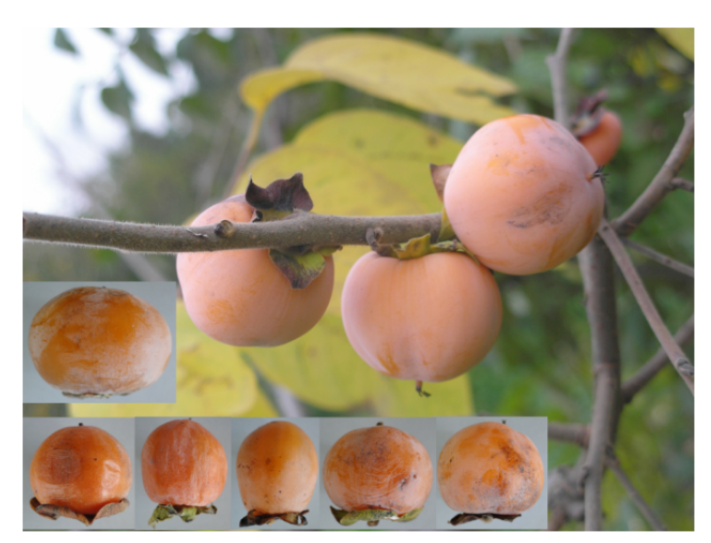

Fig. 1. Fruits of Diospyros virginiana L. 
National Botanical Garden of NAS of Ukraine (NBG) were the subject of these investigations. The raw materials were collected in the season of full ripeness (October).

\section{Chemicals and spectral measurements}

1,1-di-phenyl-2-picrylhydrazyl (DPPH) ferrous chloride, tripyridyltriazine (TPTZ), kaliumperoxodisulfat, 2,2'-azino-bis(3-ethylbenzthiazoline-6-sulphonic acid; ABTS), 6-hydroxy-2,5,7,8-tetramethylchroman-2-carboxylic acid (Trolox) and gallic acid were obtained from Sigma Chemical Co. (Sigma-Aldrich, Poland, Poznań). Methanol was obtained from POCh Poland. All chemicals and solvents were of analytical grade. All UV-V measurements were recorded on a Shimadzu UV-2401PC (Kyoto, Japan).

\section{Preparation of extracts for analysis of total polyphenols and antioxidant activity}

Around $2 \mathrm{~g}$ of fruits were homogenized and extracted with $80 \%$ aqueous methanol to a final volume of $20 \mathrm{~mL}$ at a room temperature. Extraction was performed in an ultrasonic bath (Polsonic, Poland) for 15 minutes. All extracts were filtered through pickling mixture paper filters (Whatman filter no. 1), and subjected to analyses.

\section{Determination of total polyphenol content (TPC)}

Total phenolic content (TPC) of the fruits was determined using the Folin-Ciocalteu reagent method according to Gao et al. (2000). Plant extracts $(0.1 \mathrm{~mL})$ were mixed with $0.2 \mathrm{~mL}$ of Folin-Ciocalteu reagent and $2 \mathrm{~mL}$ of $\mathrm{H}_{2} \mathrm{O}$, and, after $3 \mathrm{~min}, 1 \mathrm{~mL} 20 \%$ sodium carbonate. Total polyphenols were determined after $1 \mathrm{~h}$ of incubation at room temperature in a dark room. The absorbance of the resulting blue color was measured at $765 \mathrm{~nm}$ with a Shimadzu UV-VIS spectrophotometer. The standard cure was prepared using different concentrations of gallic acid. The results were calculated as $\mathrm{mg}$ of gallic acid equivalent (GAE/ $1 \mathrm{~g})$. All determinations were performed in triplicate.

\section{Determination of reducing power (FRAP) and radical scavenging activity}

Ferric reducing antioxidant power (FRAP) was measured using Benzie and Strain (1996). An aliquot (1.0 $\mathrm{ml}$ ) of the diluted extract was added to $3 \mathrm{ml}$ of FRAP solution (acetate buffer ( $300 \mu \mathrm{M}, \mathrm{pH} 3.6)$, a solution of $10 \mu \mathrm{M} \mathrm{TPTZ}$ in $40 \mu \mathrm{M} \mathrm{HCl}$, and $20 \mu \mathrm{M} \mathrm{FeCl}_{3}$ at 10:1:1 $(v / v / v)$ ratio). The mixture was shaken and left at room temperature for $10 \mathrm{~min}$. The absorbance was read at $593 \mathrm{~nm}$ after $10 \mathrm{~min}$ using a Shimadzu UV2401PC spectrophotometer. The standard curve was prepared using different concentrations of Trolox. The results of the assay were expressed in $\mu \mathrm{M}$ Trolox per $1 \mathrm{~g}$. All determinations were performed in triplicate.

\section{Determination of DPPH radical scavenging activity}

The DPPH free radical scavenging activity of the fruit extracts was measured from bleaching of the purple color of (2,2-diphenyl-1-picrylhydrazyl), as described by Yen and Chen (1995). Exactly $0.5 \mathrm{ml}$ solution, at different concentrations of extract, was added to $2 \mathrm{ml}$ of DPPH. The mixture was shaken and left at room temperature for $10 \mathrm{~min}$. The absorbance was measured at $517 \mathrm{~nm}$, using a Shimadzu UV2401PC spectrophotometer. The standard curve was prepared using different concentrations of Trolox. The results of the assay were expressed in $\mu \mathrm{M}$ Trolox per $1 \mathrm{~g}$. All determinations were performed in triplicate.

\section{Determination of ABTS radical scavenging activity}

ABTS (2,2'-azino-bis(3-ethylbenzothiazoline-6-sulfonic acid)) assay was based on the method of Re et al. (1999). Briefly, ABTS radical cation was generated by reacting $7 \mathrm{mM}$ ABTS and $2.45 \mathrm{mM}$ potassium persulfate via incubation at room temperature $\left(23^{\circ} \mathrm{C}\right)$ in the dark for $12-16 \mathrm{~h}$. The ABTS solution was diluted to an absorbance of $0.700 \pm 0.040$ at $734 \mathrm{~nm}$. The reagent blank reading was taken $\left(A_{0}\right)$. After the addition of $3.0 \mathrm{ml}$ of diluted $\mathrm{ABTS}^{+}$solution to $30 \mu \mathrm{l}$ of plant extract, the absorbance reading was taken exactly 6 min after initial mixing $\left(A_{t}\right)$. The standard curve was prepared using different concentrations of Trolox. Results of antioxidant activity were expressed in $\mu \mathrm{Mol}$ Trolox equivalents (TE/g). All determinations were performed in triplicate.

\section{Statistical analysis}

Analysis of variance was performed by ANOVA procedures. Statistical analysis was performed using 
Statictica 8.0. Correlations between the data were obtained using a correlation coefficient $(r)$.

\section{RESULTS AND DISCUSSION}

In the department of the fruit plants of the M. M. Gryshko National Botanical Garden of NAS of Ukraine, the gene fond the collection of American persimmon was collected, including 15 American cultivars (John Rick, Meader, weber, Prok, Yates, Szukis, supersweet, Pieper, NC 10, Hess, Geneva Long, Garretson, Evelyn, Dickie, Early Golden) and 4 Ukrainian cultivars. The different plants were assessed according to their ecological and biological properties and economic value. As result of analytical selection, the most promising forms with different characteristics (size of fruit, productivity, winter resistance, term of maturity, etc.) were chosen (Grygorieva et al., 2009; 2011; 2017).

\section{Antioxidant activity of Diospyros virginiana}

The scavenging of $\mathrm{DPPH}^{\cdot}$ free radical is a common method to evaluate the antioxidant activity of antioxidants. $\mathrm{DPPH}^{*}$ is a relatively stable free organic radical due to the delocalization of the spare electron, which reduces its capacity to be absorbed by antioxidants. Thus, DPPH ${ }^{*}$ does not dimerize, as happens with most free radicals (Pisoschi and Negulescu, 2011). The DPPH radical scavenging activity of each Diospyros virginiana genotype extract is shown in Figure 2.

The antioxidant activity of Diospyros virginiana genotypes ranged from 51.68 (DV-05) to 100.87 (DV-03) $\mu \mathrm{Mol}$ Trolox/g. The scavenging effect of extracts (by DPPH method) of the studied Diospyros virginiana genotypes decreased in the following order: DV-03 $>$ DV-02 > DV-06 > DV-01 > DV-04 > DV-05. The best activity was detected in the sample of DV-03.

Another stable free radical cation, $\mathrm{ABTS}^{+}$, was used to evaluate the antioxidant activity of the American persimmon extracts. The ABTS radical scavenging effect of extracts from Diospyros virginiana genotypes showed similar trends to that of the DPPH radical scavenging activity (Fig. 2).

As shown in Figure 2, the antioxidant activity of extracts of Diospyros virginiana genotypes measured by $\mathrm{ABTS}^{+}$ranged from 65.40 (DV-05) to 142.26

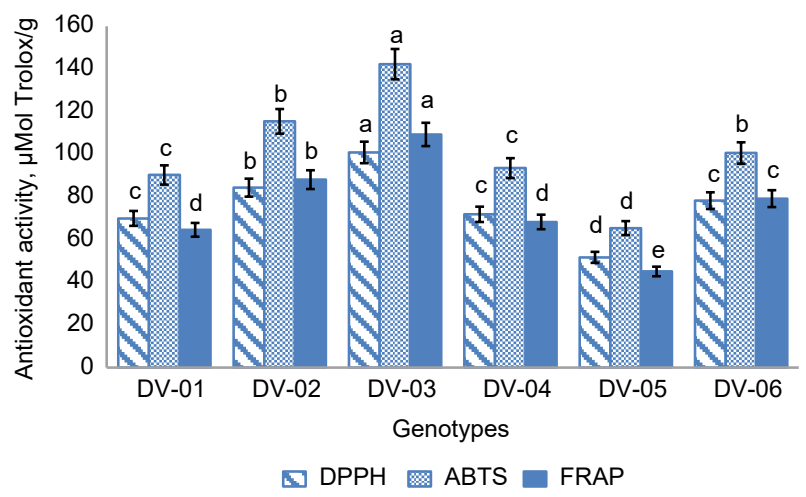

Fig. 2. Antioxidant activity of Diospyros virginiana L. extracts determined by different methods, $\mu$ Mol. Means in columns followed by different letters are different at $p=0.05$. Each value represents the mean of three independent experiments ( \pm SD)

(DV-03) $\mu \mathrm{Mol}$ Trolox/g, and had the highest results compared with other methods.

These results indicate that the American persimmon extracts have different radical scavenging activity, depending on genotype. The scavenging capacity for ABTS radical by the extracts was relatively high compared to that for DPPH radical for all genotypes. In this case the scavenging effect of the extracts (by ABTS method) of the studied Diospyros virginiana genotypes decreased in the following order: DV-03 > DV-02 > DV-06 > DV-04 > DV-01 > DV-05.

The antioxidant activity of Diospyros virginiana genotypes evaluated by FRAP method (Fig. 2) ranged from 45.06 (DV-05) to 109.30 (DV-03) $\mu \mathrm{Mol}$ Trolox/g. Ferric reducing antioxidant power assay uses antioxidants as reductants in a redox-linked colorimetric method, employing an easily reduced oxidant system. It should be noted that the results of antioxidant activity obtained in the first experiment (by DPPH method) was fairly similar to the FRAP method results. And in this case the scavenging effect of the extracts was in the same order as with the results obtained by DPPH method.

Our results compared favorably with previous studies on Diospyros kaki L. (Chen et al., 2008; Ercisli et al., 2008; Heras et al., 2017; Oksuz et al., 2015; $\mathrm{Pu}$ et al., 2013), and showed similar antioxidant activity. Chen et al. (2008) reported that the antioxidant 
activity of Diospyros kaki was higher than grape, apple and tomato. Pu et al. (2013) investigated the antioxidant activity of Diospyros kaki cultivars by ABTS, DPPH and FRAP methods. Results ranged from 47.86 to $3,716.28$, from 190.83 to $2,223.11$ and from 90.10 to $957.74 \mu \mathrm{Mol} / 100 \mathrm{~g}$ respectively. Oksuz et al. (2015) reported that antioxidant activity by ABTS and DPPH was 364.85 and $217.60 \mathrm{mg}$ TEAC/100 g respectively.

\section{Assessment of total polyphenol content}

Polyphenols are secondary metabolites of plants and are generally involved in defense against ultraviolet radiation or aggression by pathogens. In food, polyphenols may contribute to bitterness, astringency, color, flavor, odor and oxidative stability. Fruits like grapes, apples, pears, cherries and berries contain up to 200-300 mg polyphenols per 100 grams fresh weight (Pandey and Rizvi, 2009). Polyphenols are of interest because of their potential use as prophylactic and therapeutic agents in the treatment of many diseases, and much work has been presented by the scientific community which focuses on their antioxidant effects. Plant polyphenols have been studied with the intention of finding compounds which protect against a number of diseases related to oxidative stress and free radical-induced damage, such as cardiovascular and neurodegenerative diseases, cancer, diabetes, autoimmune disorders and some inflammatory diseases (Vladimir-Knežević et al., 2012).

The results for TPC determined by the Folin-Ciocalteu method ranged from $590.75 \mathrm{mg} / 100 \mathrm{~g}$ (DV-05) to $1325.12 \mathrm{mg} / 100 \mathrm{~g}$ (DV-03) (Fig. 3). Total phenolic content of the studied genotypes of Diospyros virginiana fruit extracts expressed as mg GAE/100 $\mathrm{g}$ of matter decreased in following order: DV-03 $>$ DV-02 $>$ DV-06 > DV-04 > DV-01 > DV-5.

Our results are consistent with data from research which investigated the polyphenols of Diospyros spp. such as Diospyros kaki (Achiva et al., 1997; Denev and Yordanov, 2013; Ercisli et al., 2008; Oksuz et al., 2015; Toyoda et al., 2008), Diospyros lotus L. (Ayaz et al., 1997; Gao et al., 2014). Ercisli et al. (2008) reported that great variation of total phenolic content (from 15.7 to $42.3 \mathrm{mg} \mathrm{GAE} / \mathrm{g}$ ) was observed among genotypes Diospyros kaki. Also, according to this

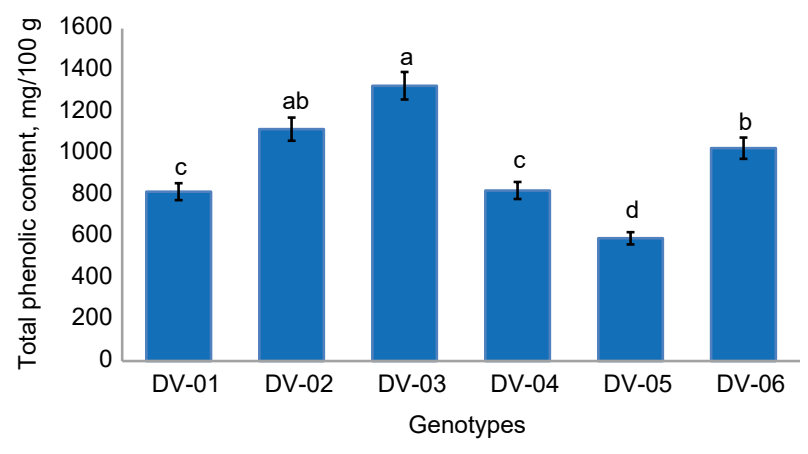

Fig. 3. Total phenolic content of genotypes of Diospyros virginiana $\mathrm{L}$. fruit extracts based on gallic acid equivalents (GAE, Line; $\mathrm{mg} / 100 \mathrm{~g}$ ). Means in columns followed by different letters are different at $p=0.05$. Each value represents the mean of three independent experiments $( \pm \mathrm{SD})$

report, the polyphenol content of Diospyros lotus acetone extract was 1.6, methanol extract - 3.3, water extract - $14.5 \mathrm{mg} \mathrm{GAE} / \mathrm{g}$ (Gao et al., 2014). The obtained results regarding antioxidant activity (Fig. 2) showed a high correlation with the results for the total phenol content.

Correlation analysis was used to explore the relationships between individual phenolic compounds and antioxidant capacities (ABTS, DPPH, and FRAP), measured for all fruit extracts from six Diospyros virginiana genotypes (Fig. 4).

The findings of this study indicate that the phenolic content presents high positive correlations with ABTS scavenging capacity, DPPH and FRAP $(r=0.982$, $p<0.05 ; r=0.985, p<0.05$ and $r=0.994, p<0.05$, respectively). There were no significant differences between the different methods of antioxidant activity determination or total phenolic content $(P>0.05)$.

Ercisli et al. (2008) found there was a poor correlation $(r=0.711)$ between total phenolic content and antioxidant activity in the Diospyros kaki samples. Zou et al. (2017) identified a slightly stronger correlation $(r=0.823)$ between total phenolic content and antioxidant activity in the Diospyros kaki samples. Several studies have reported on the relationship between total polyphenol content and antioxidant activity due to the strong correlation between these two factors in fruits (Chen et al., 2008; Fu et al., 2010; Li et al., 2011; Pu et al., 2013; Velioglu et al., 1998). 


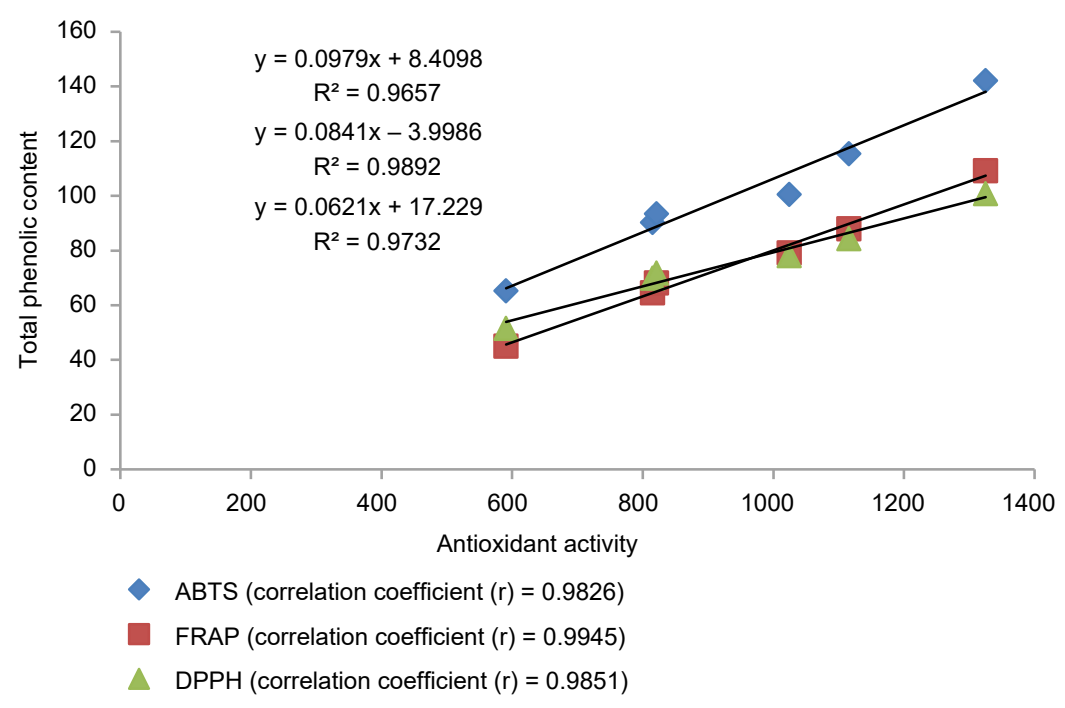

Fig. 4. Linear correlation between total phenolic content and antioxidant activity (TEAC)

\section{CONCLUSION}

The antioxidant activities and total phenolic contents of fruit extracts from six Diospyros virginiana genotypes were studied. The results showed that all fruit extracts exhibited strong antioxidant activities, which correlated positively with the total phenol contents. This study demonstrates the potential of fruits of Diospyros virginiana, grown in Ukraine, as possible source of valuable polyphenol content with high antioxidant activities and health-promoting properties. The obtained data showed that, of the three methods of determining antioxidant activity in extracts of Diospyros virginiana fruits, the strongest results were found by the ABTS method. The high contents of phenolic compounds and significant linear correlation between concentration of phenolic compounds and antioxidant activity indicated that these compounds contribute strongly to antioxidant activity.

\section{REFERENCES}

Achiva, Y., Hibasami, H., Katsuzaki, H., Imai, K., Komiya, T. (1997). Inhibitory effects of persimmon (Diospyros kaki) extract and related polyphenol compounds on growth of human lymphoid leukemia cells. Biosci. Biotechnol. Biochem., 61, 1099-1101.
Ayaz, F. A., Kadioğlu, A., Reunanen, M. (1997). Changes in phenolic acid contents of Diospyros lotus L. during fruit development. J. Agric. Food Chem., 45(7), 2539-2541. https://doi.org/10.1021/jf960741c

Bartram, I. (1772). A memoir on the distillation of persimons. Trans. Am. Philosoph. Soc., 1, 231-234.

Benzie, I. F. F., Strain, J. J. (1996). The Ferric Reducing Ability of Plasma (FRAP) as a Measure of "Antioxidant Power”: The FRAP Assay. Anal. Biochem., 239(1), 70-76.

Briand, C. H. (2005). The common persimmon (Diospyros virginiana $\mathrm{L}$.): the history of an underutilized fruit tree (16-19th centuries). Huntia, 12(1), 71-89.

Denev, P., Yordanov, A. (2013). Total polyphenol, proanthocyanidin and flavonoid content, carbohydrate composition and antioxidant activity of persimmon (Diospyros $k a k i$ L.) fruit in relation to cultivar and maturity stage. Bulg. J. Agric. Sci., 19(5), 981-988.

Ercisli, S., Akbulut, M., Ozdemir, O., Sengul, M., Orhan, E. (2008). Phenolic and antioxidant diversity among persimmon (Diospyrus kaki L.) genotypes in Turkey. Int. J. Food Sci. Nutr., 59(6), 477-482. https://doi. org/10.1080/09637480701538262

Foster, S., Duke, J. A. (1999). A field guide to medicinal plants and herbs of Eastern and Central North America. Boston: Houghton Mifflin.

Fu, L., Xu, B. T., Xu, X.-R., Qin, X.-S., Gan, R.-Y., Li, H.-B. (2010). Antioxidant capacities and total phenolic contents of 56 wild fruits from South China. Mol- 
Grygorieva, O., Kucharska, A. Z., Piórecki, N., Klymenko, S., Vergun, O., Brindza, J. (2018). Antioxidant activities and phenolic compounds in fruits of various genotypes of American persimmon (Diospyros virginiana L.). Acta Sci. Pol. Technol. Aliment., 17(2), 117-124. http://dx.doi.org/10.17306/J.AFS.2018.0544

ecules, 15, 8602-8617. https://doi.org/10.3390/molecules 15128602

Gálik, B., Bíro, D., Šimko, M., Juráček, M., Capcarová, M., Kolesárová, A., ..., Kanka, T. (2016). The effect of dietary bee pollen intake on growth performance and biochemical indicators of rats. Acta Vet. Brno, 85(1), 99-104. https://doi.org/10.2754/avb201685010099

Gao, H., Cheng, N., Zhou, J., Wang, B., Deng, J., Cao, W. (2014). Antioxidant activities and phenolic compounds of date plum persimmon (Diospyros lotus L.) fruits. J. Food Sci. Technol., 51(5), 950-956. https://doi. org/10.1007/s13197-011-0591-X

Gao, X., Ohlander, M., Jeppsson, N., Bjork, L., Trajkorski, V. (2000). Changes in antioxidant effects and their relationship to phytonurients in fruits of Sea buckthorn (Hippophae rhamnoides L.) during maturation. J. Agric. Food Chem., 48(5), 1485-1490. https://doi.org/10.1021/ jf991072g

Grygorieva, O., Brindza, J., Vietoris, V., Kucelová, L., Tóth, D., Abrahamova, V., Hricová, M. (2011). Morphological and organoleptic fruit properties of various persimmon species (Diospyros spp.). Potrav. Slovak J. Food Sci., 5(3), 11-19.

Grygorieva, O., Klymenko, S., Brindza, J., Kochanova, Z., Toth, D., Derevjanko, V., Grabovecka, O. (2009). Introduction, breeding and use of persimmon species (Diospyros spp.) in Ukraine. Acta Hort. (ISHS), 833, 5762. https://doi.org/10.17660/ActaHortic.2009.833.8

Grygorieva, O., Vergun, E., Brindza, J., Rakhmetov, D., Stehlikova, B. (2012). Ascorbic acid content changes in the leaves of selected species of Diospyros spp. genus during their growth. In: The $3^{\text {rd }}$ International Symposium on Medicinal Plants, Their Cultivation and Aspects of Uses (pp. 75-76). Petra-Jordan.

Grygorieva, O., Klymenko, S., Vergun, O., Hudz, N., Nikolaieva, N., Schubertová, Z., ..., Brindza, J. (2017). Morphological characteristics and determination of volatile organic compounds of Diospyros virginiana L. genotypes fruits. Potrav. Slovak J. Food Sci., 11(2), 612-622. https://doi.org/10.5219/808

Hamel, P. B., Chiltoskey, M. U. (1975). Cherokee plants and their uses: A 400 year history. Sylva, North Carolina: Herald Publ.

Heras, R. M.-L., Pinazo, A., Heredia, A., Andrés, A. (2017). Evaluation studies of persimmon plant (Diospyros kaki) for physiological benefits and bioaccessibility of antioxidants by in vitro simulated gastrointestinal digestion. Food Chem., 214, 478-485. https://doi.org/10.1016/j. foodchem.2016.07.104
Herkel', R., Gálik, B., Bíro, D., Rolinec, M., Šimko, M., Juráček, M., ..., Wilkanowska, A. (2016). The effect of a phytogenic additive on nutritional composition of turkey meat. J. Centr. Eur. Agric., 17(1), 25-39. http:// dx.doi.org/10.5513/JCEA01/17.1.1664

Charley, W., Mitchell, M., Kidd, K. (1999). Antibiotics laboratory medicine. In the antimycobacterial susceptibility tests (pp. 127-175). New York: Williams \& Wilkins Press.

Chen, X. N., Fan, J. F., Yue, X., Wu, X. R., Li, L. T. (2008). Radical scavenging activity and phenolic compounds in persimmon (Diospyros kaki L. cv. Mopan). J. Food Sci., 73(1), 24-28. https://doi.org/10.1111/j.1750-3841.2007. 00587.x

Chetverikova, L. S., Kichenko, V. I., Utkin, L. M. (1959). Investigation of the plants of USSR flora for the content of saponins. In: Proceedings of the All-Union Scientific Research Institute of the Medicinal and Aromatic Plants. Issue 11 (pp. 202-228). Medgiz: Moscow.

Isfahani, N. B., Hozoorbakhsh, F., Rashed, K., Havaei, S. A., Heidari, K., Moghim, S. (2014). Effect of Lagerstroemia tomentosa and Diospyros virginiana methanolic extracts on different drug-resistant strains of mycobacterium tuberculosis. Res. Pharm. Sci., 9(3), 193-198.

Ivanišová, E., Grygorieva, O., Abrahamová, V., Schubertova, Z., Terentjeva, M., Brindza, J. (2017). Characterization of morphological parameters and biological activity of jujube fruit (Ziziphus jujuba Mill.). J. Berry Res., 7(4), 249-260. https://doi.org/10.3233/JBR-170162

Kobayashi, H., Antonious, A., Pomper, K. (2017). Phenolic content and antioxidant capacity of American persimmon (Diospyros virginiana L.) teas. J. Am. Pomol. Soc., 71(2), 91-96.

Kucelova, L., Grygorieva, O., Ivanišová, E., Terentjeva, M., Brindza, J. (2016). Biological properties of black mulberry-derived food products (Morus nigra L.). J. Berry Res., 6(3), 333-343. https://doi.org/10.3233/JBR160141

Li, P. M., Du, G. R., Ma, F. W. (2011). Phenolics concentration and antioxidant capacity of different fruit tissues of astringent versus non-astringent persimmons. Sci. Hortic., 129(4), 710-714. https://doi.org/10.1016/j.scienta.2011.05.024

Mallavadhani, U. V., Panda, A. K., Rao, Y. R. (1998). Pharmacology and chemotaxonomy of Diospyros. Phytochemistry, 49(4), 901-951. https://doi.org/10.1016/ S0031-9422(97)01020-0

Nawirska-Olszańska, A., Biesiada, A., Sokół-Łętowska, A., Kucharska, A. Z. (2011). Content of bioactive compounds and antioxidant capacity of pumpkin puree en- 
riched with japanese quince, cornelian cherry, strawberry and apples. Acta Sci. Pol. Technol. Aliment., 10(1), 51-60.

Oksuz, T., Surek, E., Tacer-Caba, Z., Nilufer-Erdil, D. (2015). Phenolic contents and antioxidant activities of persimmon and red beet jams produced by sucrose impregnation. Food Sci. Technol., 3(1), 1-8. https://doi. org/10.13189/fst.2015.030101

Pandey, K. B., Rizvi, S. I. (2009). Plant polyphenols as dietary antioxidants in human health and disease. Oxid. Med. Cell Longev., 2(5), 270-278. https://doi. org/10.4161/oxim.2.5.9498

Pisoschi, A. M., Negulescu, G. P. (2011). Methods for total antioxidant activity determination: A review. Biochem. Anal. Biochem., 1, 106. https://doi.org/10.4172/21611009.1000106

Pliszka, B., Huszcza-Ciołkowska, G., Wierzbicka, E. (2016). Effects of solvents and extraction methods on the content and antiradical activity of polyphenols from fruits Actinidia arguta, Crataegus monogyna, Gaultheria procumbens and Schisandra chinensis. Acta Sci. Pol. Technol. Aliment., 15(1), 57-63. https://doi.org/10.17306/J. AFS.2016.1.6

Priya, S., Nethaji, S. (2014). Evaluation of antioxidant activity of leaf and bark extracts of Diospyros virginiana in rats. Int. J. Pharm. Tech. Res., 8(3), 1032-1035.

Priya, S., Nethaji, S. (2015). Antipyretic activity of ethanolic extract of leaf and bark of Diospyros virginiana in yeast induced pyrexia. Int. J. Pharm. Sci., 7(9), 502-504.

Pu, F., Ren, X.-L., Zhang, X.-P. (2013). Phenolic compounds and antioxidant activity in fruits of six Diospyros kaki genotypes. Eur. Food Res. Technol., 237, 923-932. https://doi.org/10.1007/s00217-013-2065-z

Re, R., Pellegrini, N., Proteggente, A., Pannala, A., Yang, M., Rice-Evans, C. (1999). Antioxidant activity applying an improved ABTS radical cation decolorization assay. Free Rad. Biol. Med., 26(9-10), 1231-1237.

Richter, A. A. (2001). The improvement of the quality of fruit cultures. Simferopol: Tavriya.

Ross, N. J., Stevens, M. H. H., Rupiper, A. W., Harkreader, J., Leben, L. A. (2014). The ecological side of an ethno- botanical coin: Legacies in historically managed trees. Am. J. Bot., 101(10), 1618-1630.

Ścibisz, I., Mitek, M. (2007). The changes of antioxidant properties in highbush blueberries (Vaccinium corymbosum L.) during freezing and long-term frozen storage. Acta Sci. Pol. Technol. Aliment., 6(4), 75-82.

Shukla, Y. N., Kapadia, G. J., Govind, J. (1989). Chemical constituents of Diospyros virginiana. Indian J. Pharm. Sci., 51(2), 73.

Sikora, E., Bieniek, M. I., Borczak, B. (2013). Composition and antioxidant properties of fresh and frozen stored blackthorn fruits (Prunus spinosa L.). Acta Sci. Pol. Technol. Aliment., 12(4), 365-372.

Toyoda, M., Sato, M., Abe, K., Sakamoto, M., Tanaka, Y., Yokoyama, N., ..., Kikuchi, Ch. (2008). Vitamin C and polyphenol content in young leaves of 11 persimmon cultivars. Nippon Shokuhin Kagaku Kogaku Kaishi, 55(7), 345-349. https://doi.org/10.3136/nskkk.55.345

Velioglu, Y. S., Mazza, G., Gao, L., Oomah, B. D. (1998). Antioxidant activity and total phenolics in selected fruits, vegetables, and grain products. J. Agric. Food Chem., 46(10), 4113-4117. https://doi.org/10.1021/ jf9801973

Vladimir-Knežević, S., Blažeković, B., Štefan, M. B., Babac, M. (2012). Plant polyphenols as antioxidants influencing the human health. In: R. Venketeshwer (Ed.), Phytochemicals as nutraceuticals - Global approaches to their role in nutrition and health (pp. 155-180). https://doi.org/10.5772/27843

Wang, X., Habib, E., Leon, F., Radwan, M. M., Tabanca, N., Gao, J., ..., Culter, S. J. (2011). Antifungal metabolites from the roots of Diospyros virginiana by overpressure layer chromatography. Chem. Biodivers., 8(12), 23312340. https://doi.org/10.1002/cbdv.201000310

Yen, G. C., Chen, H. Y. (1995). Antioxidant activity of various tea extracts in relation to their antimutagenicity. J. Agric. Food Chem., 43(1), 27-32. https://doi. org/10.1021/jf00049a007

Zou, B., Wu, J., Yu, Y., Xiao, G., Xu, Y. (2017). Evolution of the antioxidant capacity and phenolic contents of persimmon during fermentation. Food Sci. Biotechnol., 26(3), 563-571. https://doi.org/10.1007/s10068-017-0099-x 